\title{
Pemanfaatan Ruang Bersama di Rusunawa Kaligawe, Semarang
}

\author{
Public Space Use in Kaligawe's Flats, Semarang
}

\author{
Zuyyina Laksita Dewi ${ }^{1}$ \\ Universitas Diponegoro, Semarang, Indonesia \\ Nany Yuliastuti ${ }^{2}$ \\ Universitas Diponegoro, Semarang, Indonesia
}

\begin{abstract}
Abstrak: Rusunawa Kaligawe merupakan salah satu hunian vertikal yang dibangun di wilayah timur Kota Semarang. Perubahan pola permukiman dari horisontal (kampung) ke arah vertikal (rumah susun) membatasi pergerakan masyarakat dalam bersosialisasi. Rumah susun sebagai bentukan baru dari hunian seharusnya dapat mengakomodasi kebutuhan sosial masyarakat yaitu untuk berkumpul dan berinteraksi dengan sesama. Ruang publik di dalam suatu hunian rumah susun seharusnya yang dapat menampung pergaulan masyarakat sehingga meningkatkan kebersamaan di antara penghuni. Penelitian ini bertujuan untuk mengetahui pola pemanfaatan ruang-ruang bersama yang ada di Rusunawa Kaligawe sebagai wadah interaksi sosial dan faktor apa sajakah yang mempengaruhi pemanfaatan ruang-ruang bersama. Penelitian ini menggunakan pendekatan kuantitatif dengan teknik analisis statistik deskriptif dan analisis faktor dengan sampel 126 unit rumah tangga. Penelitian ini juga menggunakan pendekatan kualitatif dengan teknik analisis dekriptif komparatif. Pola pemanfaatan ruang bersama menunjukkan bahwa ruang yang dekat dengan hunian warga, seperti selasar depan hunian (koridor) lebih sering dikunjungi dan digunakan untuk berinteraksi sedangkan ruang bersama yang terletak di lantai dasar kurang diminati. Pemanfaatan ruang bersama di Rusunawa Kaligawe tidak hanya dipengaruhi oleh faktor fisik ruang, tetapi juga faktor nonfisik yaitu karakteristik masyarakat sebagai pengguna dari ruang tersebut.
\end{abstract}

\section{Kata kunci: pemanfatan ruang bersama; rumah susun}

\begin{abstract}
Rusunawa Kaligawe is one vertical housing being built in the eastern part of the city of Semarang. Changes in settlement patterns of horizontal (village) to the vertical direction (flats) restricting the movement of people to socialize. Flats as the new formation of the dwelling should be able to accommodate the social needs of the community is to gather and interact with others. Public space in a residential flats should be able to accommodate a community association thus increasing unity among residents. This study aims to determine patterns of shared spaces use in Rusunawa Kaligawe as a place of social interaction and what are the factors that affect the use of shared spaces. This study uses a quantitative approach with a descriptive statistical analysis and factor analysis with a sample of 126 household units. The study also used a qualitative approach with comparative descriptive analysis. Shared space use patterns indicate that the space close to the dwelling units, such as residential corridor more frequented and used to interact while the shared space located on the ground floor less desirable. Use of shared space in Rusunawa Kaligawe not only influenced by the physical space, but also the intangible factor that is characteristic of the community as users of the space.
\end{abstract}

Keywords: public space use; flats

\footnotetext{
${ }^{1}$ Korespondensi Penulis: Universitas Diponegoro, Semarang, Indonesia Email: dewilaksita@gmail.com

${ }^{2}$ Korespondensi Penulis: Universitas Diponegoro, Semarang, Indonesia Email: nanyuliastuti@gmail.com
} 
Pendahuluan
Pembangunan Rusunawa Kaligawe sebagai solusi pemenuhan kebutuhan perumahan bagi masyarakat tidak lepas dari berbagai permasalahan, baik teknis maupun sosial. Pola permukiman yang tadinya menyebar ke samping (kampung) berubah menjadi menumpuk ke atas (rumah susun), mendatangkan berbagai konsekuensi, yaitu ruang gerak menjadi terbatas dan pola komunikasi berubah. Selain itu, penghuni rumah susun yang sebagian besar berasal dari dari perkampungan kota dengan sifat "out door personality" yaitu lebih suka berada di luar rumah umumnya merasa kesulitan beradaptasi karena kurangnya ruang-ruang terbuka (Budiharjo, 2009).

Rumah susun sebagai bentukan baru dari tempat tinggal harus dapat mengakomodasi kebutuhan pengguna untuk bersosialisasi. Karena kebutuhan untuk bermasyarakat atau berkumpul dengan sesama merupakan kebutuhan dasar (naluri) manusia itu sendiri (Citra Amalia dkk, 2011). Oleh karena itu, adanya ruang publik, atau biasa disebut ruang bersama di dalam suatu hunian rumah susun merupakan suatu hal yang vital, karena ruang-ruang tersebut dapat menampung pergaulan masyarakat sehingga meningkatkan kebersamaan di antara penghuni.

Ruang bersama yang terdapat di Rusunawa Kaligawe terbagi menjadi dua, yaitu, ruang yang bersifat tertutup, yaitu ruang publik yang terdapat di dalam blok bangunan seperti lapangan, ruang serbaguna, selasar parkir, selasar dekat tangga dan selasar depan unit hunian. Selain itu, terdapat juga ruang publik terbuka, yaitu ruang "sisa" di luar bangunan yang sering juga disebut ruang luar (outdoor space). Namun, pada beberapa kasus ditemukan ruang bersama di rumah susun kurang berfungsi secara optimal. Hariyono (2007:193) dalam Citra Amalia dkk (2011) menyebutkan bahwa ruang yang dirancang tidak mudah terjangkau tempatnya dapat mengurangi minat penghuni untuk melakukan interaksi sosial. Selain itu, kondisi ruang yang tidak terawat dengan baik juga mengurangi minat untuk berkunjung, seperti kasus pada perumahan susun di Z.H.U.N, Algeria, Afrika Utara dimana terdapat lapangan sepak bola namun kondisinya tidak terawat dengan baik sehingga kini semakin jarang digunakan. (Naceur Farida, 2013). Oleh karena itu, perlu diketahui bagaimana pola pemanfaatan ruang-ruang bersama yang ada di Rusunawa Kaligawe sebagai wadah interaksi sosial dan faktor apa sajakah yang mempengaruhi pemanfaatan ruang-ruang bersama tersebut.

Lokasi penelitian adalah Rumah Susun Sederhana Sewa (Rusunawa) Kaligawe terletak di Kelurahan Kaligawe, Kecamatan Gayamsari, Kota Semarang. Rusunawa Kaligawe dibangun di atas lahan milik pemerintah Kota Semarang seluas 18 hektar, yang terdiri dari 7 (tujuh) twin block dimana masing-masing twin blocknya memiliki 96 unit hunian. Rusunawa Kaligawe menyediakan 288 unit tipe 21 dan 384 untit tipe 24 .

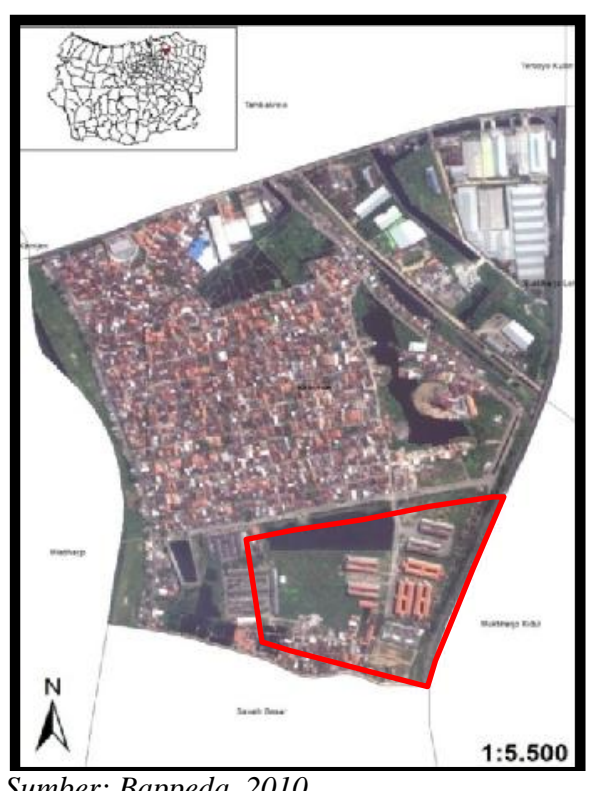

Gambar 1. Peta Citra Kelurahan Kaligawe 


\section{Kajian Pemanfaatan Ruang Bersama di Perumahan Susun}

Rumah merupakan tempat berlindung dari kedahsyatan alam (hujan, panas, angin, binatang buas, dan lain-lain). Selain sebagai tempat berlindung, Budiharjo (2009) mengatakan bahwa rumah juga tempat dimana proses sosialisasi terjadi, yaitu pengenalan adat istiadat, nilai, kebiasaan yang berlaku dalam masyarakat, juga tempat manusia memenuhi kebutuhan-kebutuhan hidupnya. Kebutuhan yang dimaksud bukan hanya sekedar mempertahankan hidup, namun juga kebutuhan akan kasih sayang, harga diri, rasa aman, dan aktualisasi diri (Abraham Maslow).

Menurut UU No 20 Tahun 2011 tentang rumah susun, Rumah Susun adalah bangunan gedung bertingkat yang dibangun dalam suatu lingkungan yang terbagi dalam bagian-bagian yang distrukturkan secara fungsional dalam arah horisontal maupun vertikal dan merupakan satuan-satuan yang masing-masing dapat dimiliki dan digunakan secara terpisah terutama untuk tempat hunian yang dilengkapi dengan bagian bersama, benda bersama dan tanah bersama dengan sasaran rumah susun adalah masyarakat berpenghasilan menengah kebawah, antara Rp. 600.000 sampai Rp. 1.500.000.

Masyarakat berpenghasilan rendah cenderung memiliki outdoor personality, yaitu tidak suka diam di rumah melainkan lebih suka beraktivitas di luar rumah. Perumahan hendaknya menyediakan tempat untuk menyalurkan hal ini, misalnya taman-taman umum untuk bermain anak-anak (Budiharjo, 2009). Selain itu, perlu dipertimbangkan adanya kompleks pertokoan yang terpisah dari flat sehingga penghuni perlu berjalan keluar dan berinteraksi.

Adanya ruang publik dalam suatu hunian vertikal merupakan hal yang vital (Francis dkk, 2012). Ruang publik di lingkungan permukiman bisa juga disebut ruang bersama atau ruang komunal (berasal dari kata communal) yang artinya, merupakan ruang yang menampung kegiatan sosial dan berhubungan dengan umum, merupakan ruang yang menampung kegiatan sosial dan digunakan untuk seluruh masyarakat atau komunitas (Wijayanti, 2000).

Untuk menganalisis pemanfaatan ruang-ruang bersama yang ada di rumah susun diukur berdasarkan kuantitas, kualitas, dan waktu penggunaan(Citra Amalia $\mathrm{dkk}, 2011$ ). Faktor-faktor yang berpengaruh terhadap penggunaan ruang bersama, meliputi faktor individu, faktor sosial, faktor fisik lingkungan, dan faktor kebijakan (Francis dkk, 2012). Sedangkan menurut Farida (2013) faktor-faktor yang mempengaruhi penggunaan ruang bersama adalah faktor sosial ekonomi penghuni dan faktor fisik lingkungan (akses, layout, mix-use, dan physical feature).

\section{Karakteristik Penghuni}

Sebagian besar masyarakat Rusunawa Kaligawe, yaitu sebesar $48 \%$ belum lama menghuni di rumah susun yaitu baru sekitar 1-3 tahun. Rumah tangga di Rusunawa Kaligawe termasuk ke dalam ukuran rumah tangga menengah, yang memiliki 1-2 anak yang tinggal dalam satu rumah. Mayoritas rumah tangga di Rusunawa Kaligawe, yaitu sebesar 93\% berisi 1 (satu) keluarga. Sedangkan rumah tangga dengan 2 keluarga proporsinya hanya 7\%. Tingkat pendidikan kepala rumah tangga di Rusunawa Kaligawe tergolong sedang, sebagian besar tamat SMA dan tamat SMP. Berdasarkan tingkat pendapatan, dapat disimpulkan bahwa sebagian besar penghuni Rusunawa Kaligawe didominasi oleh rumah tangga kelas ekonomi bawah hingga menengah, dengan pendapatan per bulan mayoritas berkisar antara Rp 1.000.000-Rp Rp 2.000.000.

\section{Karakteristik Perkumpulan Warga}

Partisipasi warga dalam komunitasnya dapat dilihat dari jumlah kegiatankegiatan yang diikutinya dan keaktifan warga dalam menghadiri pertemuan. Sebagian besar rumah tangga yaitu sebesar $30 \%$ mengikuti 4 kegiatan, yaitu perkumpulan RT, arisan PKK, rukun kematian, dan paguyuban satu blok. $21 \%$ mengikuti 5 kegiatan.

Keaktifan warga dalam perkumpulan dilihat dari frekuensi warga dalam menghadiri setiap pertemuan. $71 \%$ responden tergolong aktif dalam perkumpulan warga, karena selalu hadir dalam setiap pertemuan. Sedangkan $29 \%$ menyatakan kadang-kadang hadir dan kadang-kadang tidak hadir dalam pertemuan warga. Alasan warga dalam hal ini adalah karena pekerjaan yang tidak bisa ditinggalkan dan beberapa juga beralasan pergi ke luar kota. 


\section{Kondisi Fisik Ruang Bersama}

1. Ruang Bersama Indoor

Kondisi ruang bersama indoor dilihat dari akesibilitas (kemudahan penghuni dalam mencapai ruang) dan kondisi ruang bersama seperti ketersediaan sitting group, keberadaan vegetasi/objek menarik lainnya, pencahayaan, dan kebersihan ruang.

2. Ruang Luar (Outdoor)

Ruang luar di Rusunawa Kaligawe kondisinya buruk, dari segi layout, sebagian besar berupa lahan berpaving yang minim vegetasi. Keberadaan vegetasi berupa pepohonan sangat jarang ditemui. Selain itu, kegiatan jual beli yang memacu warga untuk datang hanya aktif saat sore hari saja.

\begin{tabular}{|c|c|c|}
\hline $\begin{array}{c}\text { Ruang } \\
\text { Bersama }\end{array}$ & Kondisi Ruang & Gambar \\
\hline Lapangan & $\begin{array}{l}\text { Lapangan tersedia di setiap } \\
\text { blok, yaitu di lantai dasar. Seluruh } \\
\text { lapangan di Rusunawa Kaligawe } \\
\text { tidak terdapat tempat duduk, } \\
\text { sebagian besar lapangan tidak } \\
\text { terdapat vegetasi, penerangan } \\
\text { kurang baik karena beberapa lampu } \\
\text { penerangan rusak, } \\
\text { kebersihannnya kurang baik. }\end{array}$ & \\
\hline $\begin{array}{l}\text { Selasar } \\
\text { Dekat } \\
\text { Tangga }\end{array}$ & $\begin{array}{l}\text { Selasar dekat tangga } \\
\text { merupakan ruang bersama yang } \\
\text { tersedia di setiap lantai, di tengah } \\
\text { hunian. Sebagian besar selasar dekat } \\
\text { tangga tidak terdapat tempat duduk, } \\
\text { tidak terdapat vegetasi, namun } \\
\text { penerangan (lampu) berfungsi } \\
\text { dengan baik, dan kebersihan baik. }\end{array}$ & \\
\hline $\begin{array}{l}\text { Ruang } \\
\text { Serbaguna }\end{array}$ & $\begin{array}{l}\text { Ruang serbaguna tersedia di } \\
\text { setiap blok, yaitu di lantai dasar. } \\
\text { Sebagian besar ruang serbaguna di } \\
\text { Rusunawa Kaligawe tidak tersedia } \\
\text { tempat duduk, tidak terdapat } \\
\text { vegetasi, penerangan baik, dan } \\
\text { kebersihan baik. }\end{array}$ & \\
\hline $\begin{array}{l}\text { Selasar } \\
\text { Depan } \\
\text { Hunian } \\
\text { (Koridor) }\end{array}$ & $\begin{array}{l}\text { Selasar depan hunian } \\
\text { merupakan ruang bersama yang } \\
\text { tersedia di setiap lantai, di depan } \\
\text { hunian warga. Sebagian besar } \\
\text { selasar depan hunian tersedia } \\
\text { tempat duduk, tidak terdapat } \\
\text { vegetasi, penerangan baik, dan } \\
\text { kebersihan baik. }\end{array}$ & \\
\hline $\begin{array}{l}\text { Selasar } \\
\text { Parkir }\end{array}$ & $\begin{array}{l}\text { Selasar parkir merupakan } \\
\text { ruang bersama yang tersedia di } \\
\text { lantai dasar setiap blok. Sebagian } \\
\text { besar selasar ini tersedia tempat } \\
\text { duduk, tidak terdapat vegetasi, } \\
\text { penerangan kurang baik karena } \\
\text { beberapa lampu penerangan rusak, } \\
\text { dan kebersihan kurang baik. }\end{array}$ & \\
\hline
\end{tabular}




\section{Metode Penelitian}

\section{Analisis Pemanfaatan \\ Ruang Bersama di Rusunawa Kaligawe}

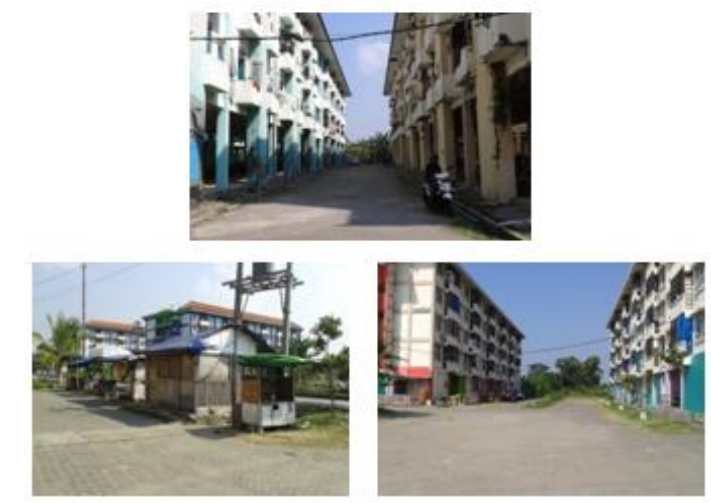

Sumber: Analisis Penyusun, 2015

Gambar 2. Kondisi Ruang Luar di Rusunawa Kaligawe
Penelitian ini menggunakan pendekatan kuantitatif dengan jumlah sampel 126 unit rumah tangga. Data yang telah dikumpulkan setelah survei lapangan akan dianalisis dengan menggunakan analisis statistik deskriptif dan analisis faktor.

Penelitian ini juga menggunakan pendekatan kualitatif dengan teknik analisis dekriptif komparatif.

Analisis Pola Pemanfaatan Ruang Bersama di Rusunawa Kaligawe

Analisis ini meliputi intensitas penggunaan ruang, kemudian kualitas interaksi yang dilihat dari jenis aktivitas yang dilakukan apakah merupakan aktivitas sosial atau tidak dan waktu penggunaan (lama interaksi).

\section{Pemanfaatan Ruang Bersama Indoor}

\begin{tabular}{|c|c|c|}
\hline $\begin{array}{c}\text { Ruang } \\
\text { Bersama }\end{array}$ & Kondisi Ruang & Gambar \\
\hline Lapangan & $\begin{array}{l}\text { Intensitas penggunaan lapangan } \\
\text { sangat kecil. Sebagian besar warga } \\
\text { hanya menggunakan sebulan sekali } \\
\text { yaitu saat kerja bakti. Pada saat } \\
\text { tertentu seperti hajatan, lapangan } \\
\text { dialihfungsikan untuk tempat parkir. }\end{array}$ & \\
\hline $\begin{array}{l}\text { Selasar } \\
\text { Dekat } \\
\text { Tangga }\end{array}$ & $\begin{array}{l}\text { Intensitas penggunaan selasar dekat } \\
\text { tangga adalah kurang dari seminggu } \\
\text { sekali. Aktivitas yang paling sering } \\
\text { dilakukan oleh warga di selasar } \\
\text { dekat tangga ini adalah rapat seperti } \\
\text { pertemuan RT dan arisan PKK. }\end{array}$ & \\
\hline $\begin{array}{l}\text { Ruang } \\
\text { Serbaguna }\end{array}$ & $\begin{array}{l}\text { Ruang serbaguna juga hanya } \\
\text { digunakan sebulan sekali yaitu saat } \\
\text { rapat paguyuban. Pada blok E dan } \\
\text { G, ruang ini digunakan untuk } \\
\text { kegiatan PAUD dan posyandu. }\end{array}$ & \\
\hline
\end{tabular}




\begin{tabular}{|c|c|c|}
\hline $\begin{array}{c}\text { Ruang } \\
\text { Bersama }\end{array}$ & Kondisi Ruang & Gambar \\
\hline $\begin{array}{l}\text { Selasar } \\
\text { Depan } \\
\text { Hunian } \\
\text { (Koridor) }\end{array}$ & $\begin{array}{l}\text { Ruang ini terletak di depan setiap } \\
\text { hunian warga sehingga intensitas } \\
\text { penggunaannya sangat tinggi, yaitu } \\
\text { lebih dari } 4 \text { (empat) kali dalam } \\
\text { seminggu. Aktivitas yang sering } \\
\text { dilakukan masyarakat di selasar } \\
\text { depan hunian ini adalah duduk } \\
\text { santai dan bercakap cakap dengan } \\
\text { tetangga di kanan kiri rumah. Selain } \\
\text { itu, aktivitas lain yang ditemukan } \\
\text { adalah aktivitas yang berhubungan } \\
\text { dengan rumah tangga seperti } \\
\text { menyapu, menjemur pakaian, dan } \\
\text { mengawasi anak bermain. }\end{array}$ & \\
\hline $\begin{array}{l}\text { Selasar } \\
\text { Parkir }\end{array}$ & $\begin{array}{l}\text { Selasar parkir, biasanya digunakan } \\
\text { jaga malam dan pada sore hari } \\
\text { banyak ditemukan anak-anak } \\
\text { bermain. Kemudian pada saat-saat } \\
\text { tertentu ruang ini digunakan untuk } \\
\text { penghuni melakukan hajatan } \\
\text { (syukuran pernikahan, ulang tahun, } \\
\text { dan lain-lain). }\end{array}$ & \\
\hline
\end{tabular}

2. Pemanfaatan Ruang Luar (Outdoor)

Ruang luar di Rusunawa Kaligawe hanya aktif saat sore hari, terutama saat weekend. Hal ini dikarenakan siang hari merupakan waktu sebagian besar penghuni bekerja, selain itu kondisi fisik ruang luar yang buruk juga mempengaruhi pemanfaatannya. Minimnya vegetasi sebagai peneduh mengurangi minat warga untuk beraktivitas saat siang hari.

Sebagian besar penggunanya merupakan anak-anak yang berusia 3-6 tahun dan wanita dewasa yang mengawasi anak-anak bermain. Aktivitas yang dilakukan warga antara lain adalah mengawasi anak-anak bermain, aktivitas jual beli, sebagian warga duduk-duduk santai dan mengobrol dengan tetangganya.

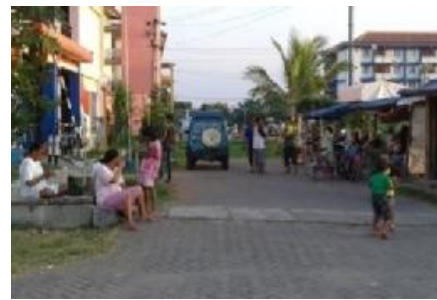

Sumber: Analisis penyusun, 2015

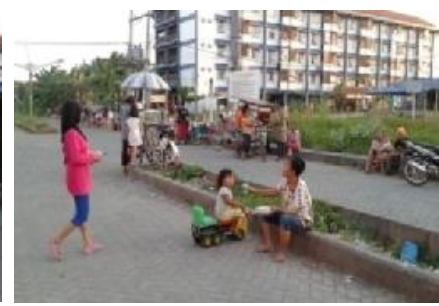

Gambar 3. Aktivitas di Ruang Luar Sore Hari 
Tabel 1. Pola Pemanfaatan Ruang Bersama

\begin{tabular}{|c|c|c|c|c|c|c|c|c|c|c|c|}
\hline \multirow[b]{2}{*}{$\begin{array}{l}\text { Jenis } \\
\text { Ruang }\end{array}$} & \multicolumn{4}{|c|}{ Intensitas Penggunaan } & \multicolumn{2}{|c|}{$\begin{array}{l}\text { Jenis Interaksi } \\
\text { Dominan }\end{array}$} & \multicolumn{2}{|c|}{ Sifat Ruang } & \multicolumn{3}{|c|}{ Skala/Jangkauan Ruang } \\
\hline & $\begin{array}{c}>4 x \\
\text { semingg } \\
u\end{array}$ & $\begin{array}{c}3-4 x \\
\text { seminggu }\end{array}$ & $\begin{array}{c}1-2 x \\
\text { seminggu }\end{array}$ & $\begin{array}{c}<1 x \\
\text { seminggu }\end{array}$ & Formal & $\begin{array}{c}\text { Non } \\
\text { formal }\end{array}$ & Terencana & $\begin{array}{c}\text { Tidak } \\
\text { terencana }\end{array}$ & $\begin{array}{c}\text { Lantai/ } \\
\text { RT }\end{array}$ & Blok & $\begin{array}{c}\text { Kawasa } \\
\mathbf{n} \\
\text { Rusun }\end{array}$ \\
\hline Lapangan & & & & $\sqrt{ }$ & $\sqrt{ }$ & & $\sqrt{ }$ & & & $\sqrt{ }$ & \\
\hline $\begin{array}{l}\text { Selasar } \\
\text { dekat } \\
\text { tangga }\end{array}$ & & & & $\sqrt{ }$ & $\sqrt{ }$ & $\sqrt{ }$ & $\sqrt{ }$ & & $\sqrt{ }$ & & \\
\hline $\begin{array}{l}\text { Ruang } \\
\text { Serbaguna }\end{array}$ & & & & $\sqrt{ }$ & $\sqrt{ }$ & & $\sqrt{ }$ & & & $\sqrt{ }$ & \\
\hline $\begin{array}{l}\text { Selasar } \\
\text { depan } \\
\text { hunian }\end{array}$ & $\sqrt{ }$ & & & & & $\sqrt{ }$ & & $\sqrt{ }$ & $\sqrt{ }$ & & \\
\hline $\begin{array}{l}\text { Selasar } \\
\text { dekat } \\
\text { ruang } \\
\text { parkir }\end{array}$ & & & & $\sqrt{ }$ & & $\sqrt{ }$ & & $\sqrt{ }$ & & $\sqrt{ }$ & \\
\hline $\begin{array}{l}\text { Ruang } \\
\text { Luar }\end{array}$ & & & & $\sqrt{ }$ & & $\sqrt{ }$ & & $\sqrt{ }$ & & & $\sqrt{ }$ \\
\hline
\end{tabular}

Pola pemanfaatan ruang bersama menunjukkan bahwa ruang yang dekat dengan hunian warga, seperti selasar depan hunian (koridor) lebih sering dikunjungi dan digunakan untuk berinteraksi. Namun, interaksi terbatas hanya sau laintai/lingkup RT saja. Sebagaimana kebiasaan yang mereka lakukan di perkampungan sebelum tinggal di rumah susun, mereka menggunakan jalan lingkungan/jalan gang di depan rumah untuk berinteraksi. jika dikaitkan dengan proses adaptasi (Bell dalam Halim, 2008) masyarakat Rusunawa Kaligawe telah berhasil beradaptasi dengan perubahan pola permukiman dengan melakukan interaksi meskipun terbatasnya ruang. Sementara ruang bersama yang terletak di lantai dasar seperti lapangan, selasar parkir, dan ruang serbaguna intensitas penggunaannya sangat kecil. Hal ini selain lokasinya jauh dari hunian (berada di lantai dasar) juga karena kurang nyaman dan tidak terjaga kebersihannya.

Ruang-ruang bersama yang terletak di lantai dasar kurang terawat dengan baik karena bentuk perumahan vertikal yang membagi warganya ke dalam lantai yang berbeda menjadikan kurangnya kesadaran warga untuk menjaga milik bersama yang berada di lantai dasar. Sebagian besar warga merasa hanya memiliki kewajiban untuk menjaga kebersihan pada lantai tempat mereka tinggal saja. Pemeliharaan lingkungan Rusunawa Kaligawe merupakan tanggung jawab pihak pengelola dan penghuni rusun namun tidak berjalan dengan baik. Kemudian sikap penghuni rusun juga belum memiliki kepedulian untuk menjaga lingkungannya.

\section{Analisis Faktor Pemanfaatan Ruang Bersama}

1. Faktor Pemanfaatan Ruang Bersama Indoor

Berdasarkan analisis faktor, disimpulkan bahwa pemanfaatan ruang bersama indoor di Rusunawa Kaligawe secara umum dipengaruhi oleh faktor fisik, yaitu kondisi ruang bersama, kemudian faktor sosial ekonomi penghuni Rusunawa Kaligawe sebagai pengguna dari ruang bersama itu sendiri, dan faktor kesediaan masyarakat berpartisipasi dalam kegiatan kemasyarakatan di lingkungan tempat tinggal mereka.

\section{Faktor Fisik Ruang}

Faktor fisik ruang bersama dinilai berdasarkan aksesibilitas ruang, ketersediaan sitting group, keberadaan vegetasi, pencahayaan dan kebersihan ruang. Semakin dekat ruang bersama dengan hunian warga, maka semakin sering ditemukan interaksi di ruang tersebut. Karena pada dasarnya, manusia cenderung 
memilih ruang yang lebih mudah dicapai untuk memenuhi kebutuhannya, termasuk kebutuhan sosialnya dibandingkan dengan ruang ruang yang jauh dari hunian. Di Rusunawa Kaligawe, ruang-ruang bersama yang berada di setiap lantai seperti selasar depan hunian (koridor) dan selasar dekat tangga lebih sering digunakan untuk berinteraksi dibandingkan dengan ruang yang berada di lantai dasar karena penghuni memilih ruang yang lebih dekat.

Tersedianya tempat duduk di ruang publik merupakan salah satu hal yang penting. Hal ini berhubungan dengan kenyamanan yang diberikan suatu ruang bersama. Ruang publik yang ideal harus menyediakan tempat duduk untuk menciptakan suasana nyaman dimana pengunjung dapat duduk berlama-lama dan bercakap-cakap. Namun, tersedia tempat duduk saja tidaklah cukup untuk memacu interaksi warga. Tempat duduk yang tersedia pengaturannya harus memungkinkan interaksi, seperti bangku yang memanjang, tempat duduk yang diatur melingkar, dan lain-lain. Di Rusunawa Kaligawe, selasar depan hunian sebagian besar tersedia sitting group. Di ruang ini juga interaksi paling banyak terjadi.

Keberadaan vegetasi pada ruang publik berfungsi ganda, yaitu sebagai elemen estetika yang menarik orang untuk berkunjung dan sebagai peneduh atau perlindungan terhadap cuaca panas saat siang hari (Hajmirsadeghi dkk, 2012), sehingga masyarakat tetap dapat beraktivitas dengan nyaman meskipun cuaca panas. Pada ruang-ruang bersma indoor Rusunawa Kaligawe, vegetasi berupa tanaman dalam pot yang disediakan secara swadaya oleh masyarakat. Vegetasi dalam ruang bersama indoor ini hanya berfungsi sebagai elemen estetika yang memberikan suasana asri pada lingkungan.

Pencahayaan merupakan aspek fisik yang mempengaruhi penggunaan ruang publik (Hajmirsadeghi dkk, 2012). Elemen ini penting keberadaannya, terutama pada malam hari. Karena hal ini berpengaruh terhadap rasa aman pengguna (Hajmirsadeghi dkk, 2012). Ruang dengan pencahayaan yang baik meminimalkan terjadinya kriminalitas sehingga masyarakat pun tidak merasa terancam beraktivitas meskipun saat malam hari. Di Rusunawa Kaligawe, ruangruang di lantai dasar penerangan kurang baik, banyak lampu yang rusak sehingga terlihat gelap saat malam hari. Hal ini membuat masyarakat jarang beraktivitas di lantai dasar.

Kebersihan ruang berpengaruh terhadap rasa nyaman. Pedro Gomes (2011) mengatakan bahwa salah satu aspek yang mempengaruhi kenyaman adalah pemeliharaan ruang termasuk di dalamnya adalah kebersihan ruang itu sendiri. Hal ini diperkuat dengan penyataan Whyte (2008) bahwa ruang publik harus menimbulkan rasa aman, bersih, dan menarik, tersedianya tempat duduk yang memadai, dan yang paling penting, dapat berfungsi sebagai tempat bagi orang untuk berinteraksi sosial. Jadi, ruang yang bersih menimbulkan kenyamanan dan menarik minat orang untuk beraktivitas.

\section{Faktor Sosial Ekonomi Penghuni}

Faktor sosial ekonomi penghuni mempengaruhi keinginan warga untuk berinteraksi dengan sesamanya. Di dalam lingkungan hunian masyarakat berpenghasilan rendah (MBR) seperti rumah susun dimana sebagian besar penghuninya cenderung memiliki outdoor personality, yaitu tidak suka diam di rumah melainkan lebih suka beraktivitas di luar rumah seperti ngobrol dengan tetangga, duduk santai, dan lain-lain (Budiharjo, 2009). Di Rusunawa Kaligawe, sebagian besar penghuninya merupakan masyarakat dengan kelas ekonomi bawah hingga menengah, sehingga keberadaan ruang bersama masih sangat dibutuhkan untuk menyalurkan kebutuhan sosial masyarakat. Hal ini tentunya berbeda kasus pada lingkungan permukiman dengan kelas sosial ekonomi tinggi dimana sifat individualis lebih dominan sehingga ruang bersama bukan merupakan kebutuhan yang vital.

\section{Faktor Kesediaan Berpartisipasi}

Terbentuknya faktor ini sesuai dengan penyataan Darmiwati (2000) dalam penelitiannya "Studi Ruang Bersama di Rumah Susun Bagi Masyarakat Berpenghasilan Rendah" menjelaskan bahwa dalam Rumah Susun (golongan 
berpenghasilan rendah) antar penghuni (yang merupakan masyarakat heterogen) memiliki kecenderungan untuk bersosialisasi satu sama lain di dalam komunitas warga. Komunitas adalah suatu hubungan antar manuasia satu dengan lainnya, antar manusia dengan kelompok dan antar kelompok satu dengan kelompok lainnya, dimana hubungan ini berlangsung secara timbal balik, dan terjadi pada semua proses kehidupan (Darmiwati, 2000). Faktor kesediaan berpartisipasi yang terbentuk dari analisis faktor ini berpengaruh terhadap penggunaan ruang bersama sebagai wadah interaksi sosial dimana semakin tinggi kesediaan warga untuk berpartisipasi dalam kegiatan masyarakat seperti perkumpulan PKK, posyandu, paguyuban dan lain-lain, maka semakin sering warga berinteraksi dengan tetangganya di ruang-ruang bersama.

\section{Faktor Pemanfaatan Ruang Bersama Outdoor}

Berdasarkan analisis deskriptif komparatif, disimpulkan bahwa faktor fisik ruang luar sangat berpengaruh terhadap penggunaan ruang luar yang ada. Ruang dengan soft element seperti vegetasi lebih banyak diminati dibandingkan dengan ruang yang berbentuk paving tanpa adanya vegetasi. Selain itu, Adanya kegiatan komersial ternyata memacu warga untuk datang. Aktivitas jajan di sore hari ini menjadi hal yang mengasyikkan terutama bagi anak-anak. Kemudian keberadaan objek yang menarik seperti boulevard dan pepohonan juga mamacu interaksi warga di ruang-ruang luar.

Selain faktor fisik, pola aktivitas masyarakat juga mempengaruhi pemanfaatan ruang luar. Ruang luar di Rusunawa Kaligawe hanya ramai saat sore hari karena sebagian besar penghuni bekerja hingga sore/malam hari sedangkan anak-anak bersekolah hingga siang hari. Selain itu, cuaca yang panas juga mengurangi minat warga untuk mengunjungi ruang luar karena minimnya vegetasi yang dapat memberi keteduhan.

Kesimpulan

\section{Daftar Pustaka}

Dari keseluruhan hasil analisis terlihat bahwa kebutuhan sosial warga di Rusunawa Kaligawe belum sepenuhnya terpenuhi. Hal ini terbukti dari interaksi warga yang terbatas hanya lingkup satu lantai saja. Sedangkan interaksi antar lantai dan antar blok kurang terakomodasi. Hal ini dikarenakan ruang bersama di lantai dasar tidak mampu menarik minat warga untuk berkunjung karena selain lokasinya jauh dari hunian (berada di lantai dasar) juga karena kurang nyaman dan tidak terjaga kebersihannya. Penghuni rusun umumnya belum memiliki kepedulian untuk menjaga lingkungannya.

Pemanfaatan ruang bersama di Rusunawa Kaligawe tidak hanya dipengaruhi oleh faktor fisik ruang namun juga faktor nonfisik yaitu karakteristik masyarakat sebagai pengguna dari ruang tersebut. Hal ini sejalan dengan teori behavior setting dimana perilaku manusia dalam ruang sangat bergantung pada kemampuan manusia dalam mempersepsikan ruang. Sedangkan faktor yang mempengaruhi persepsi manusia terhadap ruang adalah faktor dalam diri subjek yaitu manusia itu sendiri dan faktor dalam objek (lingkungan) (Purwanto, 2007). Oleh karena itu, penyediaan ruang publik pada perumahan vertikal ke depannya harus mempertimbangkan karakteristik penghuni sebagai pengguna dan faktor fisik ruang publik yang dapat meningkatkan interaksi sosial. Selain itu, diperlukan adanya pemberdayaan masyarakat untuk pemeliharaan lingkungan. Masyarakat harus memiliki rasa tanggung jawab yang tinggi dalam menjaga lingkungan mereka tidak hanya pada lantai mereka tinggal, namun juga pada lantai dasar dan ruang luar.

Amal, Citra A. dkk. 2011. Efektivitas Ruang Publik dalam Rumah Susun di Kota Makasar.

Aziz, Azhan dkk. 2011. Flats Outdoor space as a Vital social Place. Asian Journal Of EnvironmentBehaviour Studies, 3 (7).

Budiharjo, Eko. 2009. Perumahan dan Permukiman di Indonesia. Bandung: Alumni.

Buku Rusunawa Departemen Pekerjaan Umum 2012

Darmiwati, Ratna. 2000. Studi Ruang Bersama Dalam Rumah Susun Bagi Penghuni Berpenghasilan Rendah. Dimensi Teknik Arsitektur, 28 (2), 114-122.

Farida, Naceur. 2013. Effects Of Outdoor Shared Spaces On Social Interaction In A Housing Estate In Algeria. Frontiers of Architectural Research, 2, 457-467.

Francis, Jacinta dkk. 2012. Creating sense of community: The role of public space. Journal of Environmental Psychology, 32, 401-409. 
Gomes, Pedro S. 2011. Factors of Good Public Space Use. Lab'URBA, Université Paris-Est and DCSPT, GOVCOPP, University of Aveiro. 1-10.

Hajmirsadeghi, Reihaneh S, dkk. 2012. The Impact of Physical Design Factors on the Effective Use of Public Squares. International Journal of Fundamental Psychology and Social Science. 2, 3, 4956.

Pradipta, Demas dkk. 2014. Rusunawa Pekerja Industri di Kecamatan Bergas Kabupaten Semarang. Imaji, 3 (3).

Purwanto, Edi dan Wijayanti. 2009. Pola Ruang Komunal di Rumah Susun Bandarharjo. Journal of Architecture and Built Environment, 39 (1), 23-30.

Whyte, William H. 2008. The Sosial Life Of Small Urban Spaces: Project of Public Space. New York. 